a felsite. The Rev. J. F. Blake denied this. He admitted that "some eminent petrologists" had, on microscopic examination, pronounced the rock from which the gneiss has been formed to be a felsite; but he would not yield to their testimony. $\mathrm{He}$ had seen the rock in the field, and he "regretted" that these authorities had mado a mistake. It may seem a little presumptnous for $\mathrm{Mr}$. Blake to contest a determination made by three of the best petrographers in Europe; and we may suspect that if Ajax ventures to defy the lightning, Ajax will not do himself much good. Most people will consider that such an authoritative identification is absolutely decisive, and I, for one, assume it to be so. My main purpose in writing is, however, to point out that even the fieldevidence, which, in Mr. Blake's opinion, refutes the "eminent petrologists," is dead against him. Within a hundred yards of the critical section at $\mathrm{Y}$ Graig, in which the felsite passes into the gneiss, a rock which closely resembles the felsite and which also graduates into a similar gneiss, is seen to penetrate the diorite, which is more or less altered, in numerous veins, some of which are branched. Thus the microscope of the "eminent petrologists" and the eyes of the field-observer who knows where to look, lead to the same conclusion. Mr. Blake himself admits that the rock thus shown to be a felsite "passes by insensible gradations into the ordinary grey gneiss." He says that the "phenomenon is a purely local one." This is a mistake, as I can prove by examples to the contrary, though the felsitic structure is nowhere, I believe, so marked as at Y Graig; but if it were so, my case is not materially affected. If felsite is converted into a typical gneiss at $\mathrm{Y}$ Graig, all primá-facie objection to such a change disappears, and the fieldevidence receives important confirmation.

C. Callaway.

TeWkESBURY.

May 11, 1897.

TRINUCLEUS SETICORNIS AND THE UPPER BALA BEDS.

Str,- In the report of a discussion of a paper on the fauna of the Keisley Limestone, Part II (Q J.G.S., vol. liii, p. 106), the author is stated to have made the following remark: "Mr. Marr . . . . denied that Trinucleus seticornis was specially characteristic of Upper Bala beds, though some years ago he had called the Upper Bala beds of the Haverfordwest area after that fossil." I should hardly have supposed that my words required an explanation, but as the speaker on that occasion appeared puzzled, I will give it.

Mr. T. Roberts and I (in 1885) called the Upper Bala beds of Haverfordwest Trinucleus seticornis beds, because the fossil or one of its varieties is particularly abundant in those beds in that area, and we did not there discover it in beds of Middle Bala (Caradoc) age. We were perfectly justified in our action, and there is precedent for it ; e.g., no one supposes that the Leda myalis beds of the Cromer Forest Group are the only beds with Leda myalis. If we had spoken of the beds as constituting the zone of Trinucleus seticornis an explanation might be necessary, although I hold that even that 
would be admissible. I certainly supposed that all students of Lower Palæozoic geology knew that the fossil which has been determined as Trinucleus seticornis by Salter, Angelin, and many others occurs abundantly in Middle Bala (Caradoc) beds. If Mr. Reed will turn to my Sedgwick Essay "On the Classification of the Cambrian and Silurian Rocks" (published in 1883), where the Upper Bala beds are generally separated from those of Middle Bala age, he will find Trinucleus seticornis recorded as a Middle Bala fossil in North Wales (p. 39), the Lake District (p. 57), and Scandinavia (p. 76), and nowhere recorded in the Upper Bala list. Mr. Roberts and I used the term T. seticornis beds locally becanse we thought (wrongly it appears) that under the circumstances it could mislead no one.

In the above-mentioned discussion I disputed the statement that $T$. seticornis was a characteristic Upper Bala fossil, as the form which is usually taken as $T$. seticornis occurs, as remarked above, in Middle Bala beds. I have not seen Hisinger's original specimen, and have been unable to obtain access to a copy of the later (1840) edition of "Lethæa Snecica" in which the form is figured. If Mr. Reed has examined Hisinger's specimen, and can prove that the reference by Angelin, Salter, Linnarsson, Törnquist, Tullberg, and others of the common Middle Bala form to Hisinger's species is erroneous, I will cry "Peccavi." I am quite prepared to believe that there is a characteristic Trinucleus in the Upper Bala beds, but doubt whether it is Hisinger's species. I should not be surprised if the variety Bucklandi, amongst others, be eventually proved characteristic of these beds.

There are many statements in the body of Mr. Reed's paper on the Keisley Limestone with which I regret that I am unable to agree, but $I$ do not wish to trouble your readers with questions of detail, especially as I am given to understand that the fauna of the Keisley Limestone is about to be examined by a very competent palæontologist.

JoHN E. M ARR.

Cambridge, July 15, 1897.

\section{ON THE ORIGIN OF LYNCHETS.}

Sir, - Mr. E. A. Walford's article, which attempts to give a natural origin of lynchets, based on geological conditions, is not very convincing, and seems indeed to refute itself. Had he seen the many perfect examples which the Chalk Downs afford, I think he would never have suggested a natural explanation for lynchets. Joining the high road from Amesbury to Salisbury and close to the Workhouse are some very typical lynchets, all in the Upper Chalk, and yet confined to only a very small portion of it; yet, if geologic conditions are the cause, they should occur in many other localities of the Chalk area. The opponents of the artificial origin must prove why they are confined to small areas when the geologic conditions, which they consider as the cause, occur over wide areas.

Taking the Amesbury examples as typical ones, they will be seen 